Арина Дмитриева

\title{
ХОДАТАЙСТВО ПРЕДСЕДАТЕЛЯ СУДА КАК ФАКТОР УСПЕХА ОТБОРА В СУДЬИ КВАЛИФИКАЦИОННЫМИ КОЛЛЕГИЯМИ
}

В статье исследуется организация процесса отбора и назначений судей в России. Обсуждаются его основные институциальные механизмы, установившиеся после реформ 1990-х гг. Во-первых, анализируется организация работы квалификационных коллегий судей, а также роль председателей судов в формировании судейского корпуса. Во-вторых, изучаются особенности профессиональной модели отбора судей, основанной на меритократических принципах выбора наиболее квалифицированных юристов, и бюрократической модели, в которой карьера судьи выстраивается непосредственно после окончания вуза. Эмпирический анализ базируется на исследовании 957 биографий кандидатов в судьи, опубликованных на портале квалификационной коллегии в 2014-2015 гг. Анализ биографий показывает, что кандидаты в судьи преимущественно женщины, 70 \% кандидатов получали юридический опыт в аппарате суда. Для моделирования результатов назначения на должность в статье используется логистический регрессионный анализ. Результаты анализа выявили несколько закономерностей. Первое- в отборе на должность судьи определенную роль играют меритократические факторы, в частности, небольшое преимущество получают кандидаты с хорошим юридическим образованием. Второе- анализ показывает, что безусловный приоритет в отборе отдается кандидатам, получившим опыт работы в государственном секторе (в аппарате судов, прокуратуре и органах госуправления). Напротив, те, кто работали юристами в бизнес-организациях или адвокатуре, реже получают рекомендации квалификационных коллегий. Наконец, ключевую роль в отборе судей играют председатели судов. Ходатайство председателя суда повышает шансы кандидата получить рекомендацию на должность в 1,5 раза. Это оказывает существенное влияние на структуру судейского корпуса, формирует

Арина Викторовна Дмитриева- магистр социологии, LLM, научный сотрудник, Институт проблем правоприменения при Европейском университете в Санкт-Петербурге, СанктПетербург, Россия. Электронная почта: admitrieva@eu.spb.ru 
профессиональную бюрократическую культуру и снижает независимость судебной власти.

Ключевые слова: отбор судей, судебная система в России, институциальные реформы, независимость судей, исследование трудовых биографий

DOI: $10.17323 / 727-0634-2019-17-3-391-406$

В конце 1980-х и начале 1990-х гг. в большинстве постсоциалистических стран проведены структурные реформы судебной системы, направленные на то, чтобы выделить суды в особую ветвь власти и наделить их независимостью (Schwartz, Sykiainen 2012; Пашин 2003; Burbank, Friedman 2002). Сильная независимая судебная власть рассматривалась как основное условие успешных демократических реформ. Но зачастую цели построения независимой судебной системы были сведены лишь к институциальной реформе, заключавшейся в создании органов судейского самоуправления и передаче им администрирования судебной системы (Bobek, Kosař 2013). В качестве образца взята итальянская модель совета судей, преобразованного в 1948 г., после падения фашистского режима. Совет получил право проводить независимую от органов исполнительной власти кадровую политику в судебной системе, стал успешной экспортной моделью демократической организации судебной власти сначала для Португалии, Испании и Греции, а затем и для стран Восточной Европы (Benvenuti, Paris 2018). В настоящее время советы судей в той или иной форме действуют более, чем в $60 \%$ стран мира (Garoupa, Ginsburg 2009).

Европейская модель судебной реформы предполагала, что контроль над судебной системой переходит от министерств юстиции органам судейского самоуправления, к которым, наряду с советами судей, могут относиться другие институциальные объединения, например, съезд судей, где принимаются решения по различным вопросам деятельности судейского сообщества. Основными полномочиями советов судей является отбор и назначение судей, привлечение к дисциплинарной ответственности, карьерное продвижение судей. Они также могут играть определенную роль в администрировании судов, их бюджетировании и являются промежуточным органом между судебной системой и исполнительной и законодательной властью. Советы судей были созданы в большинстве постсоциалистических стран за исключением Чехии. В России советы судей получили самый большой объем полномочий в части управления кадровыми вопросами (Кӥhn 2012). Но создание советов судей не решило проблем судебной системы и не повысило независимость и подотчетность судей, напротив, создало иллюзию законченности судебной реформы и многие другие необходимые преобразования так и не были реализованы (Bobek, Kosař 2013). Советы судей во многих случаях остались номинальными институтами управления судами, а реальная власть над карьерами 
судей перераспределена между рядом других институтов- верховным судом, исполнительной и законодательной властью, председателями судов и специальными школами по подготовке судей.

Опыт других стран показывает, что в зависимости от того, как на первых этапах реформ сформированы институты отбора кадров для судебной системы, они эволюционировали в сторону большей или меньшей независимости. В тех странах, где советы судей получили максимальную власть в формировании кадров судебной системы- Венгрии, Словении, России- развилась иерархическая система, где отбор судей строится не по меритократическим принципам, а на основании персоналистских связей (Avbelj 2018). В Чехии, где формально решение по отбору судей принимает министерство юстиции, также усилилась власть председателей. Оптимальной оказалась модель, в которой полномочия по отбору были разделены между советами судей и министерством юстиции, например, в Польше, Словакии (Blisa, Kosař 2018). Влияние председателей судов на карьеру судей пропадает в тех странах, где часть решений по отбору делегирована специальным школам подготовки судей- например, в Румынии. Но опыт по внедрению школы судей в Польше свидетельствует, что хотя при ее создании снижается роль председателей в отборе кандидатов, другие аспекты судебной системы, такие как географическая и профессиональная мобильность, могут создавать проблемы при формировании судейского корпуса и заполнении вакансий (Бочаров и др. 2018).

Несмотря на проведенные реформы, порядок формирования судейского корпуса остается одной из серьезных организационных проблем российской судебной системы (Solomon, Foglesong 2000; Воскобитова 2017). Среди основных затруднений можно выделить: недостаточную прозрачность процедуры отбора (Schwartz, Sykiainen 2012), большую вовлеченность председателей судов в процесс отбора (Solomon, Foglesong 2000), узость пула кандидатов (Volkov, Dzmitryieva 2015). Как следствие, за прошедшее время задачи по совершенствованию отбора кандидатов с целью обеспечения независимости и профессионализма не были решены в полной мере (Воскобитова 2017).

Рекрутинг судей оказывает большое влияние на восприятие легитимности всей судебной системы. Как показывают предыдущие исследования, социально-профессиональное происхождение судей может влиять на их ценности, аттитюды и поведение (Volkov, Dzmitryieva 2015). Задачей настоящего исследования стало понимание критериев отбора судей. На основе анализа 957 заключений, вынесенных в 2014-2015 гг. квалификационными коллегиями судей (ККС), будет показано, что в рекомендации на должность судьи ключевую роль играет наличие ходатайства председателя суда. Другим важным фактором, определяющим успех претендента, является тип профессионального опыта- шансы кандидатов из негосударственного сектора ниже, чем юристов, работавших в государственных 
органах или судах. Статья вносит вклад в социологию профессий, поскольку представляет собой анализ профессиональной карьеры в юридической сфере, а также расширяет понимание работы ключевых для судебной системы правовых и социальных институтов.

\section{Организация системы назначения судей}

В ходе реформ начала 1990-х гг. российское судейство получило беспрецедентную, по сравнению с другими пореформенными странами, свободу самому формировать судейский корпус. Из стран Восточной Европы только в России и Венгрии министерство юстиции было полностью исключены из процесса отбора судей. В этот период сформированы органы судейского сообщества, включая региональные советы судей, и созданы ККС, задачей которых был отбор лучших кандидатов из множества претендентов. Введен обязательный экзамен на должность судьи.

\section{Квалификационные коллегии}

Создание и деятельность квалификационных коллегий регламентируются Федеральным законом «Об органах судейского сообщества в Российской Федерации» 2002 г. Квалификационные коллегии формируются в каждом регионе и их размер зависит от размера региона. В типичном случае в состав ККС входят 13 судей разного уровня, которые избираются тайным голосованием на конференции судей (Закон 1992: п. 6 ст. 11). В результате реформ 2002 г. наряду с судьями разного уровня в состав ККС были включены представители общественности и представитель Президента РФ. Их включение в ККС должно было уменьшить исключительную власть судей при оценке кандидатов на должности и вынесении дисциплинарных взысканий, повысить открытость судебной системы.

В состав экзаменационных комиссий (Закон 1992: ст. 11.1) входит равное количество судей общей юрисдикции и арбитражных судов, а также преподаватели юридических дисциплин или научные работники. После сдачи экзамена претендент ожидает открытия вакансии и обращается с заявлением в соответствующую ККС. Таким образом, на ККС ложится основная нагрузка по отбору кандидатов в судьи. Им необходимо организовать квалификационный экзамен и оценить знания кандидата, провести проверку его добропорядочности и разослать запросы в различные правоохранительные органы, оценить характеристики с рабочего места и, наконец, провести собеседование.

\section{Участие председателей судов}

Требования законодательства, касающиеся вопроса участия и влияния председателя суда на заключения квалификационных коллегий, противоречивы. С одной стороны, согласно п. 7 ст. 11 ФЗ «Об органах судейского 
сообщества», в состав ККС не могут быть избраны председатели судов и их заместители. С другой стороны, в п. 6 ст. 21 того же закона приводится норма, согласно которой, хотя председатели не могут являться членами ККС, они могут участвовать в заседаниях и, таким образом, своим авторитетом влиять на их решения. Наконец, согласно редакции закона «О статусе судей в РФ» от 2001 г., председатель суда, куда происходит назначение, наделялся «правом вето»: «В случае несогласия с решением ККС председатель суда в течение 20 дней после получения указанного решения возвращает его с мотивированным обоснованием причин своего несогласия для повторного рассмотрения в ту же ККС» (1992: ст. 5.9). Но этот абзац утратил силу с 01.09.2019 (Федеральный закон 2018). Следовательно, юридический запрет на полномочия председателя суда в рамках состава ККС нивелировался возможностями участия председателя в заседаниях ККС и его «правом вето».

Нормативные требования как будто бы ограничивают участие председателя суда в назначении судей, но на деле председатели принимают активное участие в судьбе кандидатов. Свидетельства этого участия можно обнаружить в заключениях о рекомендации на должность, о чем подробнее будет сказано ниже.

\section{Модели назначения и критерии отбора судей}

Будут ли судьи выносить беспристрастные, законные и качественные судебные решения зависит и от индивидуальных характеристик судей, и от того, как они назначаются (Guarnieri, Pederzoli 2003). В разных правовых системах используются различные модели назначения судей. В странах общего права принята модель назначения судей, которую иногда называют меритократической, иногда профессиональной, в странах континентального права отбор судей строится по модели, которую определяют как бюрократическую (Gee 2012). Модель назначения судей непосредственно влияет на степень независимости судьи. В странах с бюрократической моделью молодые судьи социализируются внутри судебной системы и становятся частью ее иерархии. В странах, где принята профессиональная модель, выше степень внешней и внутренней независимости судей (Gee 2012; Guarnieri, Pederzoli 2003). Там, где используется бюрократическая модель назначения, юристы начинают готовиться к занятию должности судьи непосредственно после окончания вуза. Эта подготовка может иметь теоретическую (как во Франции) или практическую (как в Германии) направленность. Существует возрастной ценз на вхождение в профессию: например, во Франции в школу судей набирают людей не старше 31 года (Errera 2005), в Италии- не старше 40 (Di Federico 2005).

В странах, где принята профессиональная модель отбора судей, на судейскую должность может претендовать только тот, кто уже сумел построить успешную карьеру и получил обширный опыт представления 
дел в суде. В Великобритании отбор судей осуществляет специальная комиссия. Формальных требований к возрасту и опыту работы кандидатов нет, но нужно продемонстрировать высокую квалификацию. Как следствие, в 2017 г. судей младше 40 лет было всего 2\%, а 46\% впервые назначенных судей были старше 60 лет (Ministry of Justice 2018). Кроме того, в суде преобладают профессиональные адвокаты: 33 \% до назначения в суд были адвокатами, представляющими дела в суде (барристерами), и 62\%-адвокатами, осуществляющими подготовку дел к слушаниям, но не работающими непосредственно в зале судебных заседаний (солиситорами), доля остальных профессиональных групп составляла $5 \%$.

Перечень требований к судьям, зафиксированный в Конституции и Ф3 «О статусе судей», приводит к выводу, что, проектируя модель назначения судей, законодатель имел в виду их меритократический отбор. Требования к минимальному возрасту и стажу кандидата, необходимость предоставить результаты экзамена на должность судьи, являются меритократическими по духу и предполагают, что должность судьи занимают опытные юристы на пике своей профессиональной юридической карьеры. В узком смысле меритократическая модель назначения судей подразумевает техническую оценку знаний и навыков кандидата на должность в ходе экзамена. Это единственный формальный критерий ранжирования кандидатов. В более широком смысле учитываются также профессиональные достижения кандидата, в частности, профессиональный опыт и стаж. Меритократический отбор предполагает гендерную нейтральность. Таким образом, в условиях меритократического назначения индивидуальные характеристики (пол, возраст), профессиональные характеристики (тип опыта и стаж) и формальные критерии (диплом об образовании, оценка на экзамене на судейскую должность) будут по-разному влиять на шансы кандидата быть отобранным на должность.

\section{Эмпирический анализ процесса назначения судей}

Исследование опирается на анализ заключений ККС в субъектах федерации о рекомендации на вакантную должность судьи. Эти заключения публикуются в соответствии с законом на едином портале ККС. В анализе используются заключения о результатах рассмотрения кандидатов на должность федеральных и мировых судей, вынесенные региональным ККС в 2014-2015 гг. в отношении кандидатов, впервые назначаемых на должность- всего 957 заключений из 23 субъектов федерации. Существует достаточно большая региональная вариация в подходе к написанию заключений о рекомендации на должность судьи. В наиболее полном заключении можно выделить несколько блоков информации о кандидате: биографический; карьерный; экзаменационные оценки; информация о проведенных проверках; личная характеристика; рекомендация комиссии. 
Основное преимущество этих данных заключается в том, что в них содержатся сведения как о тех, кто получил рекомендацию на должность судьи (59\%), так и тех, кому было отказано (41\%). Это предоставляет возможность сравнить успешных и неуспешных кандидатов и понять, какие факторы влияют на решения ККС.

\section{Социально-демографические и профессиональные характеристики кандидатов}

Профессиональная карьера, с одной стороны, представляет собой множество отдельных индивидуальных решений (выбор места образования, первого и последующего мест работы). С другой стороны, профессиональные траектории и развитие карьеры связаны со множеством институтов и акторов, влияющих на индивидуальное развитие. В этом смысле отбор судей зависит как от индивидуальных решений двигаться по судейской карьере, так и от набора внешних факторов, которые определяют, будет ли индивид успешен или не успешен в своем выборе профессионального пути.

Уже на этапе подачи заявлений наблюдается преобладание женщин: 74 \% заявлений на должность судьи поступили от них (табл. 1). Это является отражением тренда всего постсоветского периода, когда доля женщин выросла с 48\% в начале 1990-х до более чем $60 \%$ в 2010-е гг. И если в 1990-е увеличение доли женщин среди судей связывали с низкой оплатой и более широкими возможностями рынка труда юристов, то в последнее время судейское сообщество склонно объяснять увеличение доли женщин среди судей значительным увеличением нагрузки, с которой могут справиться только терпеливые и трудолюбивые женщины (Волков и др. 2016: 130-132).

Опыт работы и пол кандидата сильно коррелируют друг с другом: кандидаты из аппарата суда в подавляющем большинстве женщины $(85,8$ \%), кандидаты из прокуратуры- преимущественно мужчины (62,2\%). Такое соотношение отражает также и распределение мужчин и женщин по профессиональным группам: работа в аппарате суда изначально рассматривается как женская, тогда как в прокуратуре гендерное распределение более сбалансировано. Если судить по возрасту назначения на должность, то судейство является выбором, который производится на ранних этапах карьеры. Средний возраст кандидатов на должность судьи- 35,3 года, т.е. они планируют проработать в судейской должности следующие 25-30 лет. Возраст 90\% кандидатов не превышает 42 года. Лишь небольшое количество кандидатов ищут в судействе новое развитие своей карьеры в зрелом возрасте.

Согласно сигнальной теории (Spence 1973), при найме на работу работодатели не имеют полной информации о кандидате и им необходимо изучить доступную информацию для минимизации риска принять неверное решение. В таких случаях эффективным сигналом о способностях кандидата могут стать характеристики вуза, поскольку предполагается, что 
кандидат, окончивший более качественный вуз обладает рядом полезных для работы характеристик. Консенсуса относительно того, что считать «качественным» юридическим образованием в России нет ни среди ученых, ни среди преподавателей вузов, ни среди выпускников юридических факультетов. Существует несколько маркеров качественного образования: вид собственности вуза, тип вуза (классический университет/ специализированный юридический вуз/другие), уровень вуза (головной/ филиал) и форма получения образования (очное/заочное). Исходя из этого, была сконструирована переменная «хорошее образование»- это образование, полученное в головном классическом государственном университете или специализированном юридическом вузе на дневной форме обучения. Всего в выборке $32 \%$ кандидатов соответствуют этим критериям.

Наиболее важным критерием отбора является профессиональный опыт кандидата. В перечне минимальных требований к судье содержатся требования к стажу-не менее пяти лет работы по юридической профессии без уточнения, в какой сфере он должен быть получен. В среднем, стаж кандидатов составляет 9,6 лет и варьируется от 5 до 29 лет. При отборе кандидатов в судьи ККС могут принимать во внимание разнообразие трудовой биографии кандидата. Частые переходы кандидата с места на место могут, с одной стороны, сигнализировать о непостоянстве кандидата либо о его неуживчивости в коллективе. С другой стороны, частая смена работы снижает прозрачность кандидата. Репутация и профессиональные характеристики претендента, всю жизнь проработавшего в аппарате суда или в прокуратуре, на поверхности, тогда как человек, сменивший много мест работы, является для ККС «темной лошадкой». Почти половина кандидатов имеет опыт работы только в аппарате суда. Обнаруженная тенденция может быть следствием самоотбора: те, кто изначально желает выстроить карьеру судьи, считывают сигналы рынка труда, видят, что самые высокие шансы на назначение у тех, кто начинает профессиональную деятельность в аппарате суда, и выбирают работу в суде в качестве первой, не меняя ее, несмотря на интенсивность и низкую оплату.

Наконец, анализ профессионального происхождения позволяет понять уровень гомогенности кандидатов на должность судьи. Гомогенность профессионального опыта может иметь свои преимущества, например, способствовать однообразию профессиональных ценностей и паттернов трудового поведения, универсальному представлению о должном в трактовке нормативных актов. Разнообразие профессионального опыта, с другой стороны способно привнести инновации в работу, способствует расширению компетенций в разных сферах права. В результате анализа заключений ККС выделены более двадцати направлений юридической деятельности, где кандидаты в судьи могли нарабатывать профессиональный опыт. Для этих укрупненных групп выделен ведущий профессиональный опыт на основании продолжительности работы в какой-либо сфере. Если количество лет в двух 
сферах было одинаково, например, трудовой путь начат в аппарате суда, а затем человек такое же количество лет проработал в государственных органах, то основным опытом признавался последний по времени опыт работы. Поскольку для подавляющего большинства кандидатов основным является опыт работы в аппарате суда, то к нему была применена обратная операция: вместо группировки нескольких опытов, мы разделили тех, кто работал исключительно в аппарате суда на разных должностях (таких оказалась почти половина- 48,5\%), и тех, кто помимо основного опыта работы в аппарате суда работал в других сферах (17\%). Вторым по частоте является опыт работы в прокуратуре (12\%) и далее следует опыт работы в негосударственной сфере (бизнес, адвокатура, преподавание- $11 \%$ ).

Наряду с индивидуальными характеристиками на результаты отбора могут влиять и внешние факторы. Прежде всего нас интересует участие председателей судов в отборе кандидатов. В заключениях не содержится мотивировка председателей судов, а только указание на то, что он «поддерживает кандидата» или «ходатайствует о рекомендации кандидата». Всего выделяются пять сценариев предоставления председателем рекомендаций:

1. Один кандидат на одну вакантную позицию и есть прямое указание на наличие ходатайства председателя суда (23\% заключений).

2. Несколько кандидатов на вакантную позицию, прямое указание на ходатайство только в отношении одного из кандидатов (29\% заключений).

3. Указано на противоречие между мнением председателя суда, куда происходит назначение, и председателем суда субъекта (1,3\% заключений), например: «Председатель XXX районного суда города $\mathrm{N}$. поддержал заявление ФИО о рекомендации на должность мирового судьи судебного участка. Председатель ҮYY областного суда заявление ФИО о рекомендации на должность мирового судьи судебного участка XXX судебного района не поддержал».

4. Прямой отказ в ходатайстве $(0,4 \%$ заключений).

5. Нет сведений о наличии ходатайства председателя суда (46\% заключений).

На основании этих сценариев сконструирована переменная «ходатайство председателя», принимающая значение «1», если было прямое указание на ходатайство председателя в случае одного или нескольких претендентов на должность (сценарии 1 и 2) и «0» во всех остальных случаях.

Для моделирования назначения на должность нельзя не учитывать также уровень суда и тип населенного пункта, поскольку они определяют степень конкурентности судейской должности. Работа в районном суде рассматривается как более престижная и привлекательная, чем в мировом, потому можно ожидать, что на нее будут претендовать более сильные кандидаты или будет более высокая конкуренция. То же касается и работы 
в столице субъекта или в удаленном населенном пункте. Эти переменные должны быть включены в модель в качестве контрольных.

Таблицча 1

\section{Описательная статистика}

\begin{tabular}{|c|c|c|c|c|c|}
\hline Переменные & 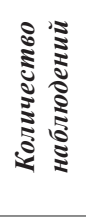 & 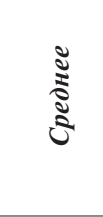 & $\mathbf{Z}$ & 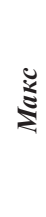 & 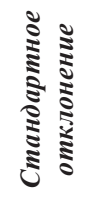 \\
\hline \multicolumn{6}{|l|}{ Зависимая переменная } \\
\hline Рекомендация ККС & 957 & 0,590 & 0 & 1 & 0,492 \\
\hline \multicolumn{6}{|l|}{ Независимые переменные } \\
\hline Мужской пол & 957 & 0,260 & 0 & 1 & 0,439 \\
\hline Хорошее образование & 957 & 0,321 & 0 & 1 & 0,467 \\
\hline Юридический стаж (лет) & 950 & 9,629 & 5 & 29 & 3,511 \\
\hline Разнообразие профессионального опыта & 957 & 1,496 & 1 & 7 & 0,757 \\
\hline \multicolumn{6}{|l|}{ Основной опыт работы } \\
\hline Только аппарат суда & 957 & 0,487 & 0 & 1 & 0,500 \\
\hline Преимущественно аппарат суда & 957 & 0,168 & 0 & 1 & 0,374 \\
\hline Прокуратура & 957 & 0,124 & 0 & 1 & 0,330 \\
\hline Полиция & 957 & 0,048 & 0 & 1 & 0,214 \\
\hline Государственные органы & 957 & 0,063 & 0 & 1 & 0,243 \\
\hline Негосударственный сектор & 957 & 0,110 & 0 & 1 & 0,313 \\
\hline Ходатайство председателя суда & 957 & 0,380 & 0 & 1 & 0,486 \\
\hline \multicolumn{6}{|l|}{ Контрольные переменные } \\
\hline Столица субъекта федерации & 957 & 0,419 & 0 & 1 & 0,494 \\
\hline Мировой судья & 957 & 0,475 & 0 & 1 & 0,500 \\
\hline Районный суд & 957 & 0,382 & 0 & 1 & 0,486 \\
\hline Областной суд & 957 & 0,00313 & 0 & 1 & 0,0559 \\
\hline Арбитражный суд & 957 & 0,139 & 0 & 1 & 0,346 \\
\hline
\end{tabular}

Примечание: доли рассчитаны для непропущенных данных

\section{Проверка моделей}

Шансы кандидатов на назначение могут быть смоделированы с помощью метода логистического регрессионного анализа. Зависимой переменной в данном случае становится факт получения кандидатом рекомендации 
на должность, закодированный как «0», если кандидат не получил рекомендацию, и «1», если был рекомендован. В первой модели проверяется гипотеза о том, что ККС при отборе кандидатов опираются на меритократические критерии. Вторая модель проверяет гипотезу о влиянии председателя на результаты отбора. В обеих моделях учтена возможная региональная вариация, а также уровень суда и тип населенного пункта. Результаты оценивания моделей приведены на рисунке 1.

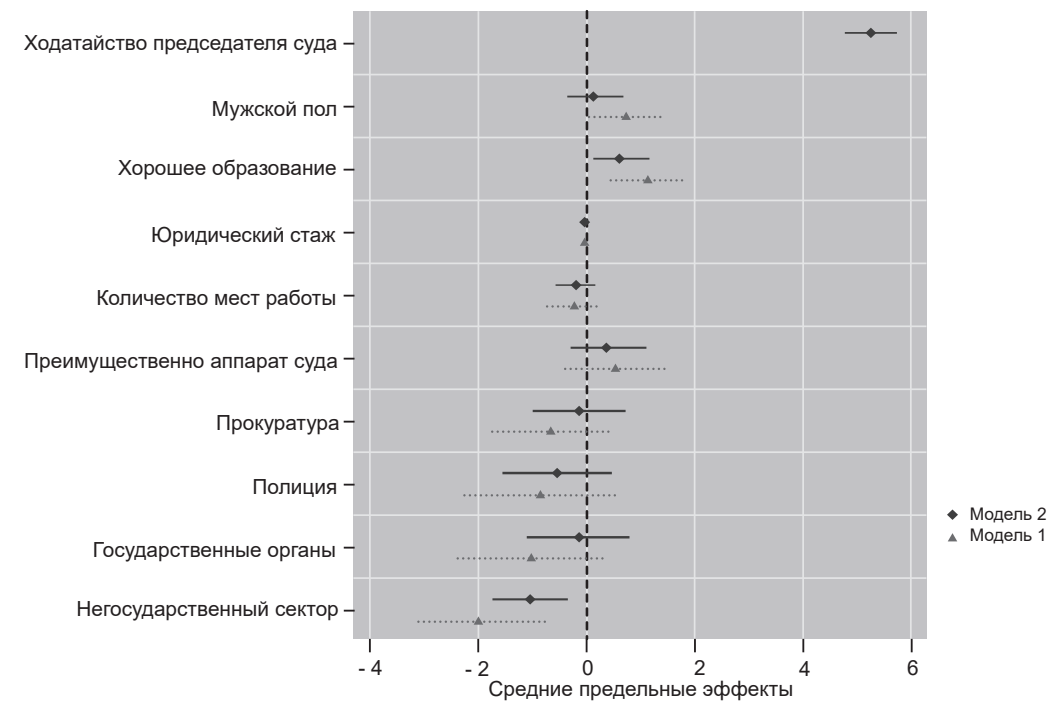

Рисунок 1. Средние предельные эффекты оценки логистической регрессии. Зависимая переменная: вероятность получить рекомендацию на должность судьи.

Из результатов регрессионного анализа можно сделать следующие выводы о тенденциях назначения судей. Во-первых, можно увидеть элементы меритократической модели. Так, пол кандидата не влияет на решение ККС, хотя из рисунка видно, что в первой модели-без учета влияния председателей судов- мужчины получают небольшое преимущество перед женщинами. Но как только учтено влияние председателя, это преимущество исчезает. Устойчивое влияние на результаты отбора имеет качество образования. Шансы кандидатов с хорошим образованием в среднем на $10 \%$ выше. Во-вторых, по сравнению с любым профессиональным опытом, полученным в государственном секторе, профессиональный опыт в негосударственном секторе сильно и отрицательно связан с шансами на получение рекомендации ККС. Если кандидат в судьи работал адвокатом или юристом на негосударственном предприятии, его шансы 
на получение рекомендации на должность падают на $20 \%$ по сравнению с кандидатами из аппарата суда. Шансы кандидатов из других профессиональных групп не отличаются от шансов кандидатов из аппарата суда.

Вторая модель показывает, что решающим фактором, определяющим возможность кандидата получить рекомендацию ККС, является ходатайство председателя суда. Если в заключении указано, что кандидата рекомендует председатель суда, его шансы вырастают более, чем на 50\%. Диагностика моделей показывает, что первая модель объясняет $18 \%$ вариации данных, тогда как добавление переменной «ходатайство председателя» увеличивает объясняющую силу модели до $48 \%$.

\section{Дискуссия и заключение}

Задача статьи показать, как организован рекрутинг судей и как распределены полномочия по их отбору между ККС и председателями судов. Формальное ограничение полномочий председателей компенсируется институтом ходатайства в пользу того или иного кандидата. При рассмотрении кандидатов, ККС всегда отдают преимущество тем, кого поддерживает председатель суда и лишь в исключительных случаях ККС принимают решения, противоречащие мнению председателя того суда, где открылась вакансия. Другие характеристики оказывают меньшее влияние на исход рассмотрения кандидатуры на должность судьи.

Такое распределение власти при отборе кандидатов оказывает долгосрочное влияние на структуру судейского корпуса. Во-первых, он гомогенизируется, а судьями становятся преимущественно бывшие сотрудники аппаратов судов. Так, в 1997 г. доля судей с опытом работы в аппарате составляла 11,4\% (Solomon, Foglesong 2000), в 2013 - 30,3\% (Volkov, Dzmitryieva 2015), а из данных этого исследования следует, что среди рекомендованных ККС в 2014-2015 гг. доля кандидатов с опытом работы в аппарате суда составила уже $69 \%$. Одно из объяснений заключается в том, что председателям проще работать с коллегами, которых они давно знают и могут оценить их профессиональные качества (Волков и др. 2016). Вероятно, в силу такой политики включается цикл самоотбора: заявление на должность судьи подают преимущественно кандидаты из аппарата судов, поскольку представители других профессиональных групп оценивают свои шансы как низкие- за них не будут ручаться председатели судов.

Наконец, тенденция набирать судей из аппарата ведет к цементированию формалистских и бюрократических ценностных установок. Опрос 2013 г. показывает, что судьи из аппарата чаще коллег с другим профессиональным опытом в качестве важных качеств судьи называют «дисциплину» и внимательность и чаще соглашаются с тем, что председатель суда должен помогать разбираться в особо сложных делах (Волков и др. 2016: 171-173). Анализ характеристик кандидатов поддерживает это утверждение: в будущих 
судьях ценятся технические компетенции, а не объективность, справедливость и независимость (Дмитриева, Савельев 2018).

Назначение кандидата с опытом работы в аппарате суда получает поддержку председателей, поскольку удобно для судебной системы тем, что он знаком с делопроизводством, дисциплинирован в соблюдении формальных требований и готов к «бумажной» нагрузке. Но эта карьерная траектория не способствует независимости и беспристрастности судей и не повышает авторитет судебной системы.

\section{Выражения признательности}

Автор выражает признательность коллегам из Института проблем правоприменения за участие в сборе данных и обсуждении результатов исследования, анонимному рецензенту, а также редактору за помощь в работе над рукописью.

\section{Список источников}

Бочаров Т. Ю., Дмитриева А. В., Скугаревский Д. А. (2018) Профессиональное образование судей: сравнительный анализ центров подготовки судей в Европе (Франция, Португалия, Польша). СПб: ИПП ЕУСПб.

Волков В. В., Дмитриева А. В., Поздняков М. Л., Титаев К. Д. (2016) Российские судьи: сочиологическое исследование профессии. М.: НОРМА.

Воскобитова Л.А. (2017) Теоретические основы судебной власти. М.: ИНФРА-М.

Дмитриева А.В., Савельев Д.А. (2018) Источники пополнения судейского корпуса РФ и роль аппарата судов. СПб: ИПП ЕУСПб.

Закон (1992) О статусе судей в Российской Федерации N 3132-1 от 26.06.1992 г.

Пашин С.А. (2003) Краткий очерк судебных реформ и революций в России. Omeчественные записки, (2): 161-182.

Федеральный закон (2002) Об органах судейского сообщества в Российской Федерации N 30-ФЗ от 14.03.2002 г.

Федеральный закон (2018) О внесении изменений в Закон Российской Федерации "О статусе судей в Российской Федерации» и Федеральный закон "Об органах судейского сообщества в Российской Федерации» N 243-ФЗ от 29.07.2018 г.

Avbelj M. (2018) Contextual Analysis of Judicial Governance in Slovenia. German Law Journal, 19 (7): 1901-1930.

Benvenuti S., Paris D. (2018) Judicial Self-Government in Italy: Merits, Limits and the Reality of an Export Model. German Law Journal, 19 (7): 1641-1670.

Blisa A., Kosař D. (2018) Court Presidents: The Missing Piece in the Puzzle of Judicial Governance. German Law Journal, 19 (7): 2031-2076.

Bobek M., Kosař D. (2013) Global Solutions, Local Damages: A Critical Study in Judicial Councils in Central and Eastern Europe. Bruges: College of Europe. 
Burbank S. B., Friedman B. (2002) Reconsidering Judicial Independence. In: S. B. Burbank, B. Friedman (eds.) Judicial Independence at the Crossroad: an Interdisciplinary Approach. New York: Sage: 9-44.

Di Federico G. (2005) Recruitment, Professional Evaluation and Career of Judges and Prosecutors in Europe: Austria, France, Germany, Italy, The Netherlands and Spain. Bologna: Research Centre for Judicial Studies.

Errera R. (2005) The Recruitment, Training, Evaluation, Career and Accountability of Members of Judiciary in France. In: G. Di Federico (ed.) Recruitment, Professional Evaluation and Career of Judges and Prosecutors in Europe. Bologna: Research Centre for Judicial Studies: $42-68$.

Garoupa N., Ginsburg T. (2009) Guarding the Guardians: Judicial Councils and Judicial Independence. The American Journal of Comparative Law, 57(1): 103-134.

Gee G. (2012) The Persistent Politics of Judicial Selection: A Comparative Analysis. In: A. Seibert-Fohr (ed.) Judicial Independence in Transition. Heidelberg: Springer: 121-145.

Guarnieri C., Pederzoli P. (2003) The Power of Judges: A Comparative Study of Courts and Democracy. Oxford: Oxford University Press.

Ministry of Justice (2018) Judicial Diversity Statistics. Available at: https://www.judiciary.uk/publications/judicial-diversity-statistics-2018/ (accessed 23 December 2018).

Kühn Z. (2012) Judicial Administration Reforms in Central-Eastern Europe: Lessons to be Learned. In: A. S. Fohr (ed.) Judicial Independence in Transition. Heidelberg: Springer: 603-617.

Schwartz O., Sykiainen E. (2012) Judicial Independence in the Russian Federation. In: A. S. Fohr (ed.) Judicial Independence in Transition. Heidelberg: Springer:971-1064.

Solomon P.H., Foglesong T. (2000) Courts and Transition in Russia. The Challenge of Judicial Reform. Boulder: Westview Press.

Spence M. (1973) Job Market Signaling. The Quarterly Journal of Economics, 87 (3):355-374.

Volkov V., Dzmitryieva A. (2015) Recruitment patterns, gender, and professional subcultures of the judiciary in Russia. The International Journal of the Legal Profession, 22 (2): 166-192. 
Aryna Dzmitryieva

\title{
THE PATRONAGE OF COURT PRESIDENTS AS A SUCCESS FACTOR IN THE SELECTION OF JUDGES BY QUALIFICATION BOARDS
}

\begin{abstract}
This article examines the process of judicial selection in Russia. It discusses the main institutional mechanisms of judicial selection and appointment, which have developed after the reforms of the 1990s. Firstly, the paper analyses the work of judge qualification boards, and the role of the presidents of the courts in the constitution of the judiciary. Second, the article examines two models of judicial selection. The first is the meritocratic model, which is based on the principle of merit: the most qualified lawyers are selected. The second is the bureaucratic model, in which the career of a judge starts immediately after graduation. The empirical analysis is based on 957 biographies of candidates for judicial position, published on the qualification board web pages in 2014-2015. The analysis of these biographies shows that candidates are predominantly women, and seventy percent of candidates obtained legal experience in the court apparatus. The article uses logistic regression to model the appointment results. It reveals several patterns of appointment. First, meritocratic factors are taken into account by qualification boards. Candidates who have a good legal education receive a slight advantage in selection. Second, the analysis shows that unconditional priority in the selection is given to candidates who have gained legal experience in public sector either in the court apparatus, the prosecutor's office or in governmental bodies. Those who worked as lawyers in business organizations or the bar have less chance of being recommended by qualification boards. Finally, the models show that court presidents play a key role in the selection of judges. The patronage of court presidents increases the chance of recommendation by fifty percent. This has a significant impact on the structure of the judiciary because it promotes a bureaucratic professional culture and reduces the independence of the judiciary.
\end{abstract}

Key words: selection of judges, judicial system in Russia, institutional reforms, judicial independence, study of professional biographies

DOI: 10.17323/727-0634-2019-17-3-391-406

\section{References}

Avbelj M. (2018) Contextual Analysis of Judicial Governance in Slovenia. German Law Journal, 19 (7): 1901-1930.

Benvenuti S., Paris D. (2018) Judicial Self-Government in Italy: Merits, Limits and the Reality of an Export Model. German Law Journal, 19 (7): 1641-1670.

Blisa A., Kosař D. (2018) Court Presidents: The Missing Piece in the Puzzle of Judicial Governance. German Law Journal, 19 (7): 2031-2076.

\footnotetext{
${ }^{1}$ Aryna Dzmitryieva-MA in Sociology, LLM, researcher, Institute for the Rule of Law at the European University at Saint Petersburg, Russian Federation. Email: admitrieva@eu.spb.ru
} 
Bobek M., Kosař D. (2013) Global Solutions, Local Damages: A Critical Study in Judicial Councils in Central and Eastern Europe. Bruges: College of Europe.

Bocharov T. Yu., Dzmitryieva A. V., Skugarevskiy D. A. (2018) Professionalnoye obrazovaniye sudey: sravnitelnyy analiz tsentrov podgotovki sudey v Evrope (Frantsiya, Portugaliya, Polsha) [Judicial Professional Education: A Comparative Study of Judicial Schools in Europe (France, Portugal, Poland)]. St. Petersburg: IRL EUSP.

Burbank S. B., Friedman B. (2002) Reconsidering Judicial Independence. In: S. B. Burbank, B. Friedman (eds.) Judicial Independence at the Crossroad: an Interdisciplinary Approach. New York: Sage: $9-44$.

Di Federico G. (2005) Recruitment, Professional Evaluation and Career of Judges and Prosecutors in Europe: Austria, France, Germany, Italy, The Netherlands and Spain. Bologna: Research Centre for Judicial Studies.

Dzmitryieva A. V., Saveliev D. A. (2018) Istochniki popolneniya sudeyskogo korpusa RF i rol ' apparata sudov [Sources of Replenishing the Judiciary of the Russian Federation and the Role of the Court Apparatus]. St. Petersburg: IRL EUSP.

Errera R. (2005) The Recruitment, Training, Evaluation, Career and Accountability of Members of Judiciary in France. In: G. Di Federico (ed.) Recruitment, Professional Evaluation and Career of Judges and Prosecutors in Europe. Bologna: Research Centre for Judicial Studies:42-68.

Federal Law (2002) On the Bodies of Judicial Community in the Russian Federation N 30-FZ from 14.03.2002.

Federal Law (2018) On Amendements of Law 'On the Status of Judges in the Russian Federation' and Federal Law 'On the Bodies of Judicial Community in the Russian Federation' No243-FZ from 29.07.2018.

Garoupa N., Ginsburg T. (2009) Guarding the Guardians: Judicial Councils and Judicial Independence. The American Journal of Comparative Law, 57 (1): 103-134.

Gee G. (2012) The Persistent Politics of Judicial Selection: A Comparative Analysis. In: A. Seibert-Fohr (ed.) Judicial Independence in Transition. Heidelberg: Springer: 121-145.

Guarnieri C., Pederzoli P. (2003) The Power of Judges: A Comparative Study of Courts and Democracy. Oxford: Oxford University Press.

Ministry of Justice (2018) Judicial Diversity Statistics. Available at: https://www.judiciary.uk/ publications/judicial-diversity-statistics-2018/ (accessed 23 December 2018).

Kühn Z. (2012) Judicial Administration Reforms in Central-Eastern Europe: Lessons to be Learned. In: A. S. Fohr (ed.) Judicial Independence in Transition. Heidelberg: Springer: 603-617.

Law (1992) On the Status of Judges in the Russian Federation No 3132-1 from 26.06.1992.

Pashin S. A. (2003) Kratkiy ocherk sudebnykh reform i revolyutsiy v Rossii [Essay on judicial reforms and revolutions in Russia]. Otechestvennyye Zapiski [Annals of the Fatherland], (2): 161-182.

Schwartz O., Sykiainen E. (2012) Judicial Independence in the Russian Federation. In: A. S. Fohr (ed.) Judicial Independence in Transition. Heidelberg: Springer:971-1064.

Solomon P. H., Foglesong T. (2000) Courts and Transition in Russia. The Challenge of Judicial Reform. Boulder: Westview Press.

Spence M. (1973) Job Market Signaling. The Quarterly Journal of Economics, 87 (3): 355-374.

Volkov V., Dzmitryieva A. (2015) Recruitment Patterns, Gender, and Professional Subcultures of the Judiciary in Russia. The International Journal of the Legal Profession, 22 (2): 166-192.

Volkov V. V., Dzmitryieva A. V., Pozdnyakov M.L., Titaev K. D. (2016) Rossiyskiye sudi: sotsiologicheskoye issledovaniye professii [Russian Judges: A Sociological Study of the Profession]. Moscow: NORMA.

Voskobitova L. A. (2017) Teoreticheskiye osnovy sudebnoy vlasti [Theoretical Foundations of the Judiciary]. Moscow: INFRA-M. 